\title{
Distribution, habitat, and conservation status of the West Indian manatee Trichechus manatus in French Guiana
}

\author{
Benoît de Thoisy, Thomas Spiegelberger, Sylvie Rousseau, Grégory Talvy, Ingrun Vogel \\ and Jean-Christophe Vié
}

\begin{abstract}
Interview surveys of 116 coastal residents and fishermen and surveys by motorboat were conducted in 2000 and 2001 in French Guiana in order to assess the distribution, habitats and conservation status of the West Indian manatee Trichechus manatus. There were 72 reported sightings of manatees, and we made 10 sightings during river surveys. Interviews suggested that manatees may be less abundant than in the recent past, but are still present and regularly sighted all along the coast and in estuaries up to $80 \mathrm{~km}$ inland. The main reason for any recent decline is probably hunting for meat, pressures from development and, in some areas, pollution from maritime traffic. Although only opportunistically caught, manatees are still poached. In some areas they are killed for cultural beliefs, but only on a small scale. The main
\end{abstract}

habitat for the manatee in French Guiana is estuarine mangroves. A survey at Coswine, an area where manatees have been sighted year-round, indicated that this mangrove area is characterized by biotic and abiotic factors within the range known to provide suitable habitat for the species. However, habitats for manatees in French Guiana are limited and receive little formal protection, and the species' status is based more on fortuitous protection than on any active conservation. Public awareness programmes for the manatee are currently being developed by local NGOs, but a regional conservation programme is also required.

Keywords Bycatch, coastal areas, French Guiana, manatee, Trichechus manatus.

\section{Introduction}

The West Indian manatee Trichechus manatus is an aquatic mammal that occurs in the coastal waters of more than 20 countries of the Caribbean region. Strictly herbivorous, the manatee inhabits nearshores waters, lagoons, estuaries, grass swamps, mangroves and lowland forests (Lefebvre et al., 1989). Because of former over-harvesting, current habitat loss and a poor ability to recover from population decreases, the species is categorized as Vulnerable on the IUCN Red List (IUCN, 2002), and is now legally protected in all of its range. In French Guiana, an administrative unit of France, it has been protected by Ministerial Decree since 1986. However, because of the inaccessibility of most of the coastal areas, there are only anecdotal reports of manatees in the country (Best \& Texeira, 1982), and its conservation status has never been assessed. The importance of the manatee in traditional

Benoît de Thoisy (Corresponding author) Sylvie Rousseau, Grégory Talvy, Ingrun Vogel, Jean-Christophe Vié ${ }^{1}$ Association Kwata, BP 672, F-97335 Cayenne cedex, French Guiana. E-mail: thoisy@kwata.org

Thomas Spiegelberger Technical University of Munich, Department of Vegetation Ecology, Am Hochanger 2, D-85350 Freising, Germany

${ }^{1}$ Also at: IUCN Species program, Rue Mauverney, 28, CH-1196 Gland, Switzerland.

Received 12 July 2002. Revision requested 26 September 2002. Accepted 9 April 2003. cultures, both in Caribbean islands and in South America, has been recognized (Baughman, 1946; O'Shea et al., 1988), but has never been specifically studied in French Guiana, although it has been in neighbouring Surinam (Duplaix \& Reichard, 1978).

Mitochondrial DNA studies suggest that the West Indian manatee population consists of three subpopulations, one of which is located along the coastal part of eastern Venezuela, Guyana, Suriname, French Guiana, and the Brazilian state of Amapá (Fig. 1; Garcia-Rodriguez et al., 1998), thus increasing the necessity of developing a regional conservation plan. The objectives of this study, as with studies of the West Indian manatee in Surinam (Duplaix \& Reichard, 1978) and north-east Brazil (Domning, 1981; Borobia \& Lodi, 1992), were to assess the current distribution and status of the species, conduct a preliminary characterization of habitats used, identify threats, and evaluate the species' traditional importance in relation to its conservation.

\section{Methods}

Information regarding manatees and their habitats were gathered using both interviews and river surveys by motorboat. As with similar studies elsewhere (Belitsky \& Belitsky, 1980; Mou Sue et al., 1990; Reynolds et al., 1995; Jiménez-Pérez, 1999, 2002) interviews were conducted with local people belonging to the main ethnic groups 


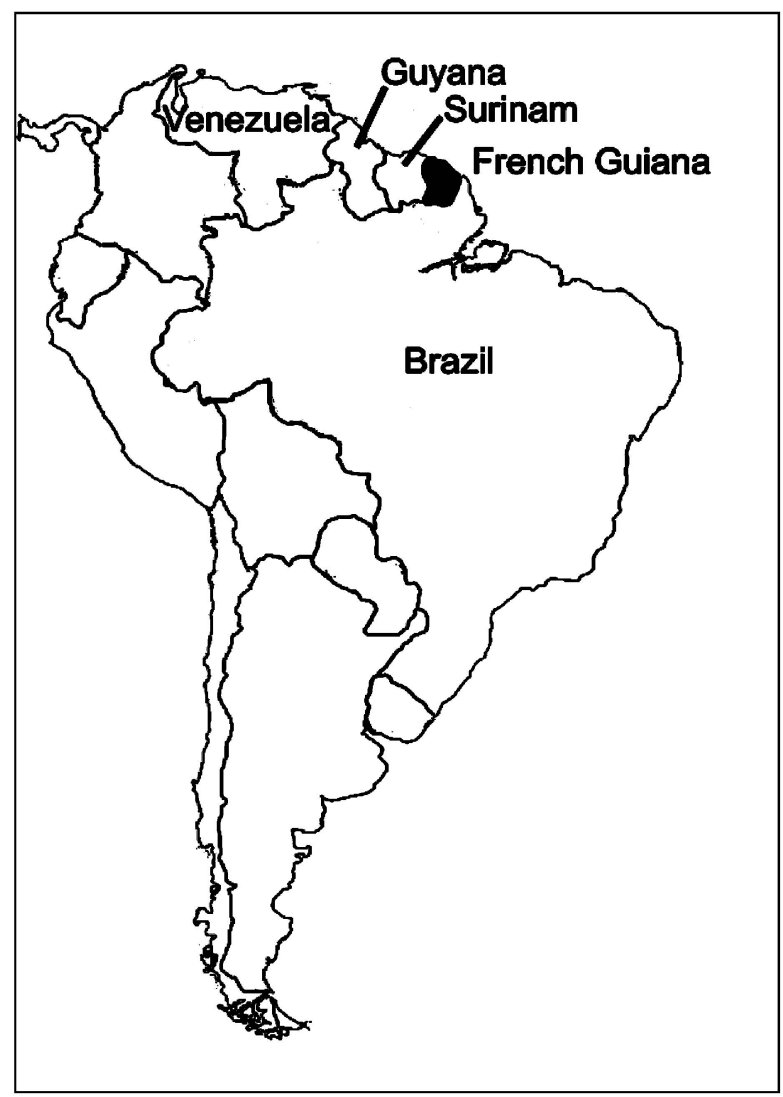

Fig. 1 The location of French Guiana in South America.

of the coastal area: Amerindians (the Kaliña and Palikur tribes), Bush negroes (descendants of escaped African slaves), Creoles, Europeans and Brazilians. These interviews were conducted in all 12 French Guianan cities and villages located along the coast and on large river mouths, and included 35 people identified as key informants (fishermen, hunters, protected habitat managers, law enforcement officers, and members of local NGOs); fishermen on the Brazilian side of the Oyapock river (Oiapoque city; Fig. 2) were also interviewed. Interviews were conducted in French or Portuguese (by BT and GT), without interpreters, and in an informal manner. During discussions, people were asked about past and recent manatee observations, including location, habitat, date, activities, as well as traditional uses, knowledge of relevant laws and the species' natural history, and concerns about its status. Shorter interviews, concerning the date and place of recent sightings, were conducted with 81 other local people. During the study period (June 2000 - June 2001) all these persons were interviewed two or three times, resulting in a total of 225 interviews.

The interviews allowed us to identify a large estuarine mangrove area $\left(80 \mathrm{~km}^{2}\right)$, Coswine, in the north-west of the country as a major habitat for manatees (Fig. 2). We carried out a preliminary botanic survey and an assessment of the basic physical and chemical parameters of the water, including depth, water temperature and salinity, in this area during July - September 2001 in order to ascertain its suitability for manatees.

\section{Results}

\section{Distribution and habitat}

Based on the 72 recent (1999 and later) sightings reported during interviews and 10 sightings during our river surveys, it appeared that the manatee is still present all along the coast and in most estuaries (Table 1, Fig. 2), although older fishermen suggested that manatees were more numerous and/or more easily seen some decades ago. On larger rivers (Oyapock, Approuague and Maroni) sightings were reported up to $80 \mathrm{~km}$ inland. Manatees were most often observed alone (46 sightings) and in pairs (32 sightings). Sightings of three adults together were reported twice; on one occasion, two adults and a calf was observed, and on another occasion seven adults were observed together.

Interviewees indicated that the manatee's main habitats were coastal and estuarine mangroves, where $72 \%$ of the reported sightings occurred. Manatees were also sighted close to rocky coastal areas (11\% of sightings), and some observations were reported in the Kaw region, a grass swamp. Less frequently, sightings were reported in rivers where they passed through gallery and marsh forests. No sightings in deep sea water were reported, but records were common along the rocky coast of a small island $5 \mathrm{~km}$ offshore. No variations in sightings and habitat use were identified between dry and wet seasons.

The Coswine area is forested and located in the north-west of the country (Fig. 2). The greatest number of sightings were made in this area (Table 1), suggesting that the species may be permanently resident there. Rhizophoraceae was the predominant plant family in the area, accounting for $25 \%$ of plants present in marsh forests and up to $100 \%$ of those found in some mangrove areas. Rhizophora racemosa was the dominant plant species, and other common species were Zygia cataratae, Macherium lunatum, Pachira aquatica, Montrichardia arborescens, Acrostichum aureum, Dalbergia monetaria and Rhabdadenia biflora. There was no submerged aquatic vegetation. Water temperature was $26.2-30.1^{\circ} \mathrm{C}$, salinity was $0.0-1.3 \%$, and water depth $2.5-6.6 \mathrm{~m}$.

\section{Threats and cultural perceptions}

In the eastern part of the country, interviewees reported that the manatee is still hunted for meat, and for Brazilians the manatee is still a game species. However, both in French Guiana and in Brazil people were aware of the 

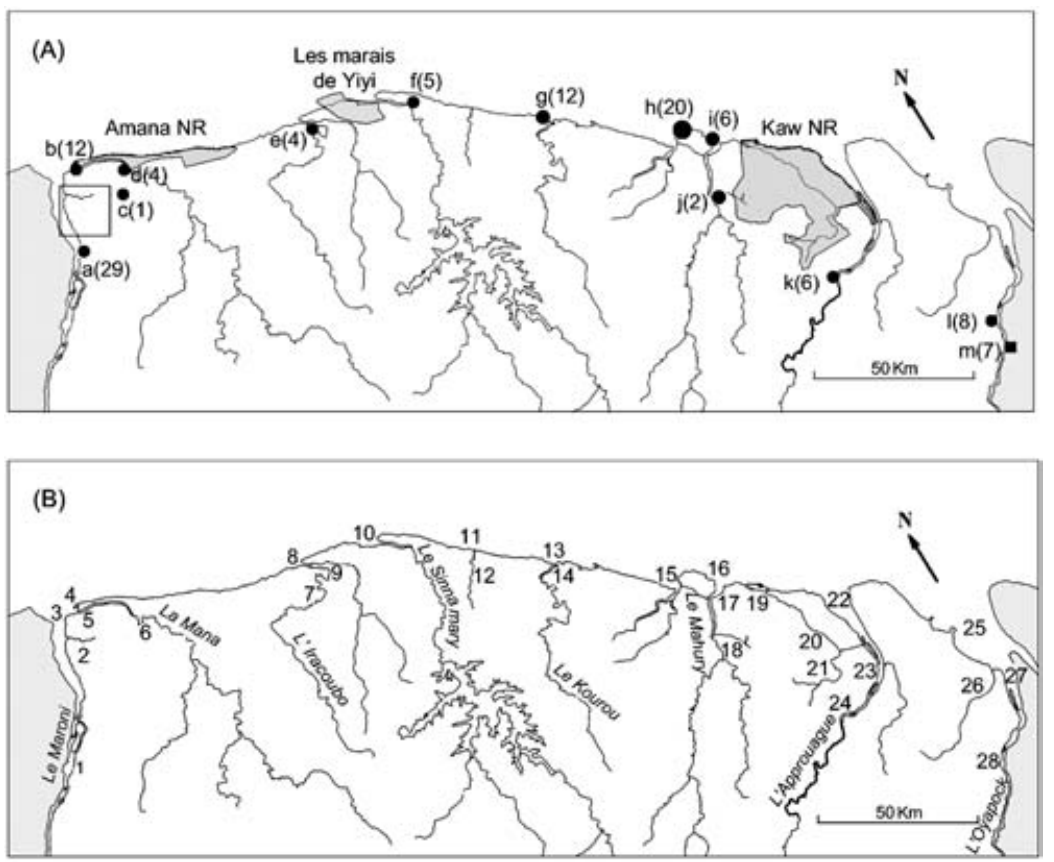

Fig. 2 The coastal region of French Guiana (see Fig. 1 for location in South America) indicating in (A) the locations (a-m, with the number of people interviewed in parentheses) where people were interviewed (see text for details) about recent manatee sightings (a, St Laurent; b, Awala; c, Javouhey; d, Mana; e, Iracoubo; f, Sinnamary; g, Kourou; h, Cayenne; i, Rémire-Montjoly; j, Roura; k, Régina; 1, St Georges; $\mathrm{m}$, Oiapoque, in Brazil), the location of the Coswine area (rectangle), the two Nature Reserves (NR), and Les marais de Yiyi, which is the largest area under the protection of the Conservatoire du Littoral (see text for details), and in (B) locations where manatees were recently sighted (numbers refer to detailed descriptions in Table 1).

legally protected status of the species. Captures are carried out with a harpoon, and occur opportunistically during fishing activities. Less than 10 manatees were reported to have been captured during the last 2 years. Only four accidental captures in nets were reported (Table 1). Except in the estuaries of the Cayenne and Kourou rivers the intensity of boat traffic is low in areas used by manatees, and may not be a significant threat.

French Guiana is highly diverse culturally, and interviews also revealed that manatees have a major sacred place in some of the traditional cultures. The species is believed by some to be a water spirit moloko, occuring in some Carib Amerindian and Bushnegroe legends together with the tapir Tapirus terrestris and the tucuxi Sotalia fluviatilis. In the west of the country manatees may also be killed by Amerindians and Bush negroes for their ear bones, which are believed to have various therapeutic (aphrodisiac, anti-fever and digestive pain) and charm properties. For other ethnic groups no cultural role for manatees was identified, but a lack of knowledge about the species was generally apparent.

\section{Discussion}

The survey technique used in this study, based on both direct and reported sightings, resulted in a set of data from discontinuous observation sites, and did not allow the assessment of manatee population size or of any decrease in numbers, as reported by some of the interviewees. However, we have confirmed that the manatee is present in French Guiana, and although sightings are not common, they occur all along the coastline. Compared to areas where suitable habitats are more extensive and diverse (Jiménez-Pérez, 2002), group sizes reported in French Guiana and in Surinam (Duplaix \& Reichard, 1978) are small; to further examine this, studies are required that assess the respective contributions of habitat quality and anthropogenic pressure. As in other parts of this species' range (Belitsky \& Belitsky, 1980; O'Shea et al., 1988; Mou Sue et al., 1990) population size may have decreased over the last two centuries due to extensive hunting (Bertram \& Bertram, 1963). Illegal poaching still appears to occur in French Guiana, although at a low intensity.

Unlike in Amapá State in Brazil and in Surinam and Guyana, extensive grass swamps are rare in French Guiana, and the narrowness of the alluvial coastal plain naturally limits available habitats (Bertram \& Bertram, 1964). Estuaries and the lower reaches of freshwater rivers are thus the main suitable habitat for the manatee. The habitat characterization that we conducted at Coswine indicated that this mangrove area is a relatively homogenous habitat 
Table 1 Recent (1999-2001) manatee sightings (see Fig. 1 for locations) reported by interviewees and made during our river surveys, with habitat type, and other relevant information, findings or observations noted during interviews.

\begin{tabular}{|c|c|c|c|c|}
\hline $\begin{array}{l}\text { Reference on } \\
\text { Fig. } 2\end{array}$ & $\begin{array}{l}\text { Location of } \\
\text { sighting(s) }\end{array}$ & $\begin{array}{l}\text { No. of } \\
\text { sightings* }\end{array}$ & Habitat & General information, findings or observations \\
\hline 1 & Maroni river & 4 & marsh forest & General local familiarity with manatees \\
\hline 2 & Coswine & $8 / 3$ & mangrove & $\begin{array}{l}\text { Regular sightings year-round; one accidental capture, } \\
\text { animal eaten }\end{array}$ \\
\hline 3 & Maroni river & 5 & estuarine mangrove & Regular sightings year-round \\
\hline 4 & Les Hattes & 3 & beach & $\begin{array}{l}\text { In the Amana Nature Reserve; } 2 \text { adults and } 1 \text { calf } \\
\text { observed once }\end{array}$ \\
\hline 5 & Mana river & 2 & estuarine mangrove & $\begin{array}{l}\text { In the Amana nature reserve; } 3 \text { adults together } \\
\text { observed once }\end{array}$ \\
\hline 6 & Mana river & 2 & marsh forest & Rice fields close by \\
\hline 7 & Iracoubo & 1 & marsh forest & Sighting in a forested creek \\
\hline 8 & Iracoubo & 1 & estuarine mangrove & Some local knowledge of manatees \\
\hline 9 & Counamama & 1 & mangrove & Some local knowledge of manatees \\
\hline 10 & Sinnamary & 1 & estuarine mangrove & Some local knowledge of manatees \\
\hline 11 & Malmanoury & $1 / 1$ & $5 \mathrm{~km}$ offshore, close to rocks & Some local knowledge of manatees \\
\hline 12 & Malmanoury & 1 & estuarine mangrove & Some local knowledge of manatees \\
\hline 13 & Kourou & 1 & along the beach & Limited local knowledge of manatees \\
\hline 13 & Kourou & $4 / 1$ & rocky coast & Sightings during the wet season \\
\hline 14 & Kourou & 1 & estuarine mangrove & Commercial port nearby; only one recent sighting \\
\hline 15 & Cayenne river & $0 / 1$ & estuarine mangrove & Commercial port nearby; only one recent sighting \\
\hline 16 & Bourda & $4 / 1$ & rocky coast & $\begin{array}{l}\text { Sightings during the wet season, } 3 \text { adults observed } \\
\text { once }\end{array}$ \\
\hline 16 & Ilet la Mère & $3 / 1$ & offshore island, rocky coast & 7 animals observed once \\
\hline 17 & Mahury & 1 & estuarine mangrove & Commercial port nearby; only one recent sighting \\
\hline 18 & Mahury & $0 / 1$ & marsh forest & Sighting in a forested creek \\
\hline 19 & Kaw river & 3 & estuarine mangrove & $\begin{array}{l}\text { In the Kaw nature reserve; limited local knowledge } \\
\text { of manatees }\end{array}$ \\
\hline 20,21 & Kaw river & 1 & swamp & One accidental capture, animal eaten \\
\hline 22 & Approuague & 5 & estuarine mangrove & Regular sightings \\
\hline 23 & Approuague & 1 & mangrove & 2 accidental captures, animals eaten \\
\hline 24 & Approuague & 1 & marsh forest & Sighting $70 \mathrm{~km}$ inland \\
\hline 25 & Oyapock & 7 & estuary & General local familiarity with manatees \\
\hline 26 & Ouanary river & 4 & mangroves & Regular sightings \\
\hline 27 & Oyapock & $5 / 1$ & mangroves & Major poaching site \\
\hline 28 & Oyapock & 1 & marsh forest & Sighting $80 \mathrm{~km}$ inland \\
\hline
\end{tabular}

*Number of sightings reported during interviews/our sightings during boat surveys.

characterized by biotic and abiotic factors within the range known to provide suitable habitat for manatees: relatively shallow warm water, both brackish and fresh, and plant species (Rhizophora sp., Montrichardia arborescens, Rhabdadenia sp. and Pachira aquatica) known to be consumed by the manatee elsewhere in its range (Bertram \& Bertram, 1964; Best, 1981; Domning, 1981; Jiménez-Pérez, 1999). In contrast grasses, which elsewhere are a major food item for the manatee (Jiménez-Pérez, 2002), are absent from Coswine but, as in other areas (Domning, 1981), the manatee appears to be able to consume other plant species. The relatively pristine state and quietness of the area may play a major role in the suitability of Coswine for manatees.

Economically, French Guiana is a relatively developed country but habitat alteration, identified in other countries as one of the major threats to the manatee (Lefebvre et al., 1989), is limited. Development and associated activities in French Guiana are generally on the landward side of the coastal mangroves because mangrove areas have traditionally been considered unsafe and to lack economic value. The net effect is that mangrove areas provide a relatively pristine and undisturbed habitat, although their legal protection is limited. There are only two coastal nature reserves providing protection to the manatee, the Amana Nature Reserve and the Kaw Nature Reserve, and the Conservatoire du Littoral, a government adminisitrative unit, ensures protection of some small and fragmented areas. In all, c. 31\% of the coastal and estuarine areas are legally protected (Fig. 2); outside these areas the legal status of mangroves is ambiguous under French law. Although suitable as manatee habitat, the mangrove areas of French Guianan may not be sufficiently extensive to support a resident population, with the 
possible exception of the Coswine area. Because movements of manatees may occur between French Guina and the western part of Brazil, Surinam and Guyana (Garcia-Rodriguez et al., 1998) an adequate management plan for the species will need to be at the regional scale.

Data on environmental contamination by toxins are lacking in French Guiana and potential impacts on manatees and other marine life is therefore difficult to assess. Although there are few large industries, the emptying of boats' fuel tanks is a common practice in commercial and other fishing ports (B.T., pers. obs.). Rice fields in the western part of the country may have negative impacts locally, as prohibited insecticides such as Dieldrine, Aldrine and DDT may still be used (Garrouste, 1998). The possible impacts of gold mining, especially with the use of mercury and cyanide in the upper reaches of some rivers, as well as pollution from the European spaceport at Kourou, have not been evaluated. Direct threats, such as hunting for meat and for local customs, appear to occur at only low levels, although as much of our data were acquired through interviews this may potentially have underestimated the levels of poaching and bycatch. However, we noted a general disinterest in hunting amongst younger people, and the traditional sacred status of the species may help to prevent illegal hunting in some areas.

Our work indicates that manatees still occur in French Guiana, but that their status is based more on the fortuitous protection of the species and of its habitats than on any active conservation plan for the coastline and its fauna. Further ecological data need to be acquired, including studies on the movements of manatees along the coastline of French Guiana and its neighbouring countries, and assessment of the potential effects of pollutants. Public awareness programmes for the species, taking into account the cultural factors of particular ethnic groups, are currently being developed by local NGOs (particularly kwata, Sépanguy and Arataii) but, given the movements of manatees along the coastline, a wider educational programme needs to be established with neighbouring countries. A regional conservation programme is also required, ideally including an efficient policy of law enforcement, and with some consideration given to the extension of protected areas, particularly around the estuary of the Oyapock river on the border with Brazil, and the Maroni river on the border with Surinam.

\section{Acknowledgements}

The interview survey was funded by the European Union, the French Ministry of Environment, the NGO Kwata, and WWF-France. Financial support for the habitat characterization of the Coswine area was provided by the University of Erlangen-Nuremberg, Papierverein Petershausen and Deutscher Akademischer Auslandsdienst. We are grateful to the staff of the Herbier de Cayenne, in particular Françoise Crozier, Marie-Françoise Prévost and Ana Bernhard for their field assistance, and to A. Puthon for the maps. Greg Bossart, Ignacio Jiménez and an anonymous referee reviewed the manuscript and provided useful comments.

\section{References}

Baughman, J.L. (1946) Some early notices on American manatees and their mode of capture. Journal of Mammalogy, 27, 234-239.

Belitsky, D.W. \& Belitsky, C.L. (1980) Distribution and abundance of manatees Trichechus manatus in the Dominican Republic. Biological Conservation, 17, 313-319.

Bertram, G.C.L. \& Bertram, C.K.R. (1963) The status of manatees in the Guianas. Oryx, 7, 127-135.

Bertram, G.C.L. \& Bertram, C.K.R. (1964) Manatees in the Guianas. Zoologica, 49, 115-120.

Best, R.C. (1981) Foods and feeding habitats of wild and captive Sirenia. Mammal Review, 11, 3-29.

Best, R.C. \& Teixeira, D.M. (1982) Notas sobre a distribuicão e "status" aparentes dos peixes-bois (Mammalia: Sirenia) nas costas amapaenses brasileiras. Boletim Fundacão Brasileira para a Conservacão da Natureza (Río de Janeiro), 17, 41-47.

Borobia, M. \& Lodi, L. (1992) Recent observations and records of the West Indian manatee Trichechus manatus in northeastern Brazil. Biological Conservation, 59, 37-44.

Domning, D.P. (1981) Distribution and status of manatees Trichechus ssp. near the mouth of the Amazon river, Brazil. Biological Conservation, 19, 85-97.

Duplaix, N. \& Reichard, H.A. (1978) History, Status, and Protection of the Caribbean Manatee Trichechus manatus manatus in Suriname. Unpublished Report. Rare Animal Relief Effort and United States Fish and Wildlife Service, USA.

Garcia-Rodriguez, A.I., Bowen, B.W., Domning, D., MignucciGiannoni, A.A., Marmontel, M., Montaya-Ospina, R.A., Morales-Vela, B., Rudin, M., Bonde, R.K. \& McGuires, P.M. (1998) Phylogeography of the West Indian manatees (Trichechus manatus): how many populations and how many taxa? Molecular Ecology, 7, 1137-1149.

Garrouste, R. (1998) Impacts écologiques de la riziculture dans la région de la basse Mana et conservation des écosystèmes littoraux. JATBA revue d'ethnobiologie, 40, 137-146.

IUCN (2002) 2002 IUCN Red List of Threatened Species. IUCN, Gland, Switzerland [http: / / www.redlist.org, accessed 7 July 2003].

Jiménez-Pérez, I. (1999) Estado de conservación, ecología y conocimiento popular del manatí (Trichechus manatus, L.) en Costa Rica. Vida Silvestre Neotropical, 8, 18-30.

Jiménez-Pérez, I. (2002) Heavy poaching in prime habitat: the conservation status of the West Indian manatee in Nicaragua. Oryx, 36, 272-278. 
Lefebvre, L.W., O'Shea, T.J., Rathbun, G.B. \& Best, R.C. (1989) Distribution, status, and biogeography of the West Indian manatee. In Biogeography of the West Indies: Past, Present and Future (ed. C.A. Woods), pp. 567-620. Sandhill Crane Press, Gainesville, USA.

Mou-Sue, L.L., Chen, D.H., Bonde, R.K. \& O'Shea, T.J. (1990) Distribution and status of manatees Trichechus manatus in Panama. Marine Mammals Science, 6, 234-241.

O'Shea, T.J., Correa-Vianna, M., Ludlow, M.E. \& Robinson, J.G. (1988) Distribution, status, and traditional significance of the West Indian manatee Trichechus manatus in Venezuela. Biological Conservation, 46, 281-301.

Reynolds, J.E., Szelitowski, W.A. \& León, M.A. (1995) Status and conservation of manatees Trichechus manatus manatus in Costa Rica. Biological Conservation, 71, 193-196.

\section{Biographical sketches}

Benoit de Thoisy is a conservation biologist working as scientific coordinator for Kwata, a non-governmental organization in French Guiana. Projects developed by Kwata focus on wildlife management and on threatened species such as giant otters, marine turtles, manatees, black caimans, and primates. Thomas Spiegelberger and Sylvie Rousseau conducted the habitat characterization as part of their graduate courses in botanical and marine mammal science, respectively. Gregory Talvy, whose area of interest is in public awareness and sustainable development, conducted the interview survey together with Benoit de Thoisy. Ingrun Vogel is the President of Kwata, and she has research interests in wildlife diseases. Jean-Christophe Vié created and formely directed Kwata, and his research interests are in wildlife health and conservation. 